\title{
PARASITOLOGY
}

\author{
A SUPPLEMENT TO THE \\ JOURNAL OF HYGIENE
}

\author{
EDITED BY \\ GEORGE H. F. NUTTALL, F.R.S. \\ Quick Professor of Biology in the University of Cambridge \\ AND
}

A. E. SHIPLEY, F.R.S.

Reader in Zoology in the University of Cambridge

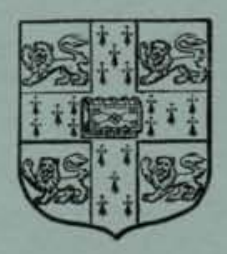

CAMBRIDGE

AT THE UNIVERSITY PRESS

LONDON: FETTER LANE, C. F. CLAY, MANAGER

AND H. K. LEWIS, GOWEB STREET

EDINBURGH: 100 , PRINCES STIEET

BERLIN : A. ASHER \& CO.

LEIPSIC: ВRОСКНАUВ

NEW YORK: G. P. PUTNAM's SONS

BOMBAY AND CALCUTTA : MACMHLAN \& CO., LTD.

Price Seven Shillings net 


\section{A TREATISE ON PLAGUE}

Dealing with the Historical, Epidemiological, Clinical, Therapeutic and Preventive Aspects of the Disease

by

W. J. SIMPSON, M.D. Aberd., F.R.C.P. Lond., D.P.H. Camb.

Professor of Hygiene, King's College, London; Lecturer on Tropical Hygiene, London School of Tropical Medicine; formerly Health Officer, Calcutta; Medieal Adviser to the Government of Cape Colony, during the outbreak of Plague in 1901; Commissioner for the Colonial Office to inquire into the causes of the continuance of Plague in Hong Kong.

Royal 8vo. Buckram. Pp. xxiv +466 .

With 6 maps and 34 illustrations. Price 16s. net

"Authoritative, comprehensive, and practical. He has given to the practical physician an accurate guide to the diagnosis and treatment... The sanitarian will read of the way in which to deal practically with an epidemic." Lancet

\section{TICKS}

\section{A Monograph of the Ixodoidea}

By GEORGe H. F. NUTTall, M.D., Ph.D., Sc.D., F.R.S., CECIL WARBURTON, M.A., F.Z.S., W. F. COOPER, B.A., F.Z.S., F.L.S. and L. E. ROBINSON, A.R.C.Sc. (London)

PART I. THE ARGASIDAE.

With 116 text figures and 3 plates. Royal 8vo. 5s. net

$$
\text { PART II. IXODIDAE. }
$$

With 153 text figures and 4 plates. Royal 8vo. 12s. net.

This book will deal with the Classification, Structure and Biology of Ticks, the study of the group having occupied the authors for several years. Practically all that has been published on the subject has received adequate consideration.

The book will be issued in four or more parts, which will be complete in themselves. A complete bibliography to the work will appear as a separate Fasciculus simultaneously with Part II.

\section{THE JOURNAL OF AGRICULTURAL SCIENCE}

Edited by

Professor R. H. BIFFEN, M.A., Cambridge, A. D. HALL, M.A., F.R.S., Rothamsted, and Professor T. B. WOOD, M.A., Cambridge.

The Journal of Agricultural Science is issued in quarterly parts of about 100 pages, with plates and figures, four parts constituting a volume.

Volumes I, II and III now ready. In Four Parts, paper covers, 15s. net per volume. Bound in Buckram, 18s. 6d. net per volume.

The subscription price, payable in advance, is 15s. per volume (post free); single numbers $5 s$. net. Subseriptions may be sent to any Bookseller, or to $\mathrm{Mr}$ C. F. Clay, Manager, Cambridge University Press, Fetter Lane, London, E.C. 


\section{PARASITOLOGY}




\section{CAMBRIDGE UNIVERSITY PRESS}

Zlondon: FETTER LANE, E.C.

C. F. Clay, Manager

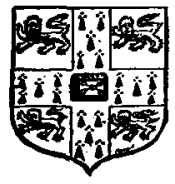

(ETinbutgh: 100, PRINCES STREET

Zunton: H. K. LEWIS, 136, GOWER STREET, W.C.

Berlin: A. ASHER AND CO.

Ileipzig: F. A. BROCKHAUS

Jew 16ark: G. P. PUTNAM'S SONS

Bombay and Talcutta: MACMILLAN AND CO., LTD.

All rights reserved 


\title{
PARASITOLOGY
}

\section{A SUPPLEMENT TO THE \\ JOURNAL OF HYGIENE}

\author{
EDITED BY \\ GEORGE H. F. NUTTALL, F.R.S. \\ Quick Professor of Biology in the University of Cambridge \\ AND \\ A. E. SHIPLEY, F.R.S. \\ Reader in Zoology in the University of Cambridge
}

\section{Volume IV I9II}

\author{
Cambridge \\ at the University Press \\ I 912
}




\section{Uambrioge:}

PRINTED BY JOHN GLAT, M.A.

AT THE UNIVERSITY PRESS 


\title{
CONTENTS
}

\author{
No. 1 (March).
}

Gilruth, J. A., Sweet, Georgina, and Dodd, Sydney. Observations on the occurrence in the blood of various animals (chiefly monotremes and marsupials) of bodies apparently identical with Anaplasma marginale Theiler, 1910. (With Plate I) . .

Huffuan, O. V. and Wherry, Wy. B. A description of four Filaria loa from the same patient. (With Plate II) . . . .

Drew, G. Harold. A note on the application of Giemsa's Romanowsky stain to the blood and tissues of marine invertebrates . . .

Porter, Annie. Some remarks on the genera Crithidia, Herpetomonas

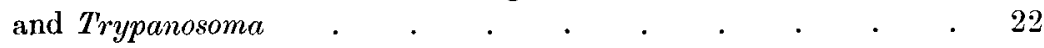

Hindee, Edward. The passage of Trypanosoma gambiense through mucous membranes and skin . . . . . . •

Mackinnon, Doris L. On some more protozoan parasites from Trichoptera. (Plate III and 8 Text-figures) . • • . 28

Nuttall, George H. F. and Merriman, G. The process of copulation in Ornithodorus moubata. (With 1 Text-figure). . . .

Nuttall, Geonge H. F. On the adaptation of ticks to the habits of their hosts. (With 26 Text-figures) . . . . . . . 46

ВАсот, A. W. The persistence of Bacillus pyocyaneus in pupae and inagines of Musca domestica raised from larvae experimentally infected with the bacillus. . . . . . . . . 68

Huffman, Otтo V. The embryos of Filaria loa. (With Plate IV) . 75 
No. 2 (June).

DArLING, S. T. The probable mode of infection and the methods used in controlling an outbreak of equine trypanosomiasis (Murrina) in the Panama Canal zone . . . . . . . .

SANT' ANNA, José F. On a disease in man following tick-bites and

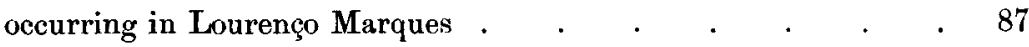

NutTald, George H. F. On symptoms following tick-bites in man . 89

Seidelin, Harald. An iron-haematein stain. With remarks on the Giemsa stain. (With Plate V) . . . . . . .

Swellengrebel, N. H. and Strickland, C. Some remarks on Dr Swingle's paper "The transmission. of Trypanosoma lewisi by rat fleas," etc. . . . . . . . . . . . . . .

Swellengrebel, N, H. Note on the morphology of Herpetomonas and Crithidia, with some remarks on "physiological degeneration." (With 12 Diagrams)

Woolley, Padl G. and Huffman, Otto V. The ova of Schistosoma japonicum and the absence of spines . . . . . . . . 131

Hindee, Edward. The transmission of Spirochaeta duttoni . $\quad .133$

Woodcock, H. M. A reply to Miss Porter's note entitled "Some remarks on the genera Crithidia, Herpetomonas and Trypanosoma"

Ponter, Annie. Further remarks on the genera Crithidia, Herpetomonas and Trypanosoma, and Dr Woodcock's views thereon . 154

Howard, C. W. An experiment in fumigation of ticks . . . 164

Merriman, Gordon. The geographical distribution of Ornithodorus moubata (Murray, 1877). (With a Map) • . . $\quad$ • $\quad \cdot \quad \cdot 168$

Maxwelt-Lefrov, H. Notes on entomological boxes. . . . 174

\section{No. 3 (October).}

Nuttall, George H. F. Notes on Ticks. I. (1) Ixodes caledonicus, description of male, together with considerations regarding the structure of the foot in male Ixodes. (2) Types of parasitism in ticks, illustrated by a diagram, together with some remarks upon longevity in ticks. (3) Regarding the loss of life in ticks occurring on wandering hosts. (With 2 Figures) . . 
Hindle, Edward. The relapsing fever of Tropical Africa. A

Wells, R. T. Aerial contamination as a fallacy in the study of amoebic infections by cultural methods. (With Plate VI) .

McCoy, George W. A microfilaria (Microfilaria rosenaui n. sp.) from the California ground squirrel (Citellus beecheyi). (With Plate VII)

Strickland, C. Description of a Herpetomonas parasitic in the alimentary tract of the common green-bottle fly, Lucilia sp. (With Plates VIII and IX and 2 Text-figures)

Porter, Annie. The structure and life history of Crithidia pulicis, n. sp., parasitic in the alimentary tract of the human flea, Pulex irritans. (With Plate X) . . . . . .

Acton, Hugh W. and Harvey, W. F. The nature and specificity of Negri bodies. (With Plate XI and 2 Text-figures) . . .

Wenron, C. M. Oriental sore in Bagdad, together with observations on a gregarine in Stegonyia fasciata, the haemogregarine of dogs and the flagellates of house flies. (With Plates XII-XVI and 36 Text-figures) .

\section{No. 4 (December).}

Swellengreber, N. H. The life-history of Pleistophora gigantea Thélohan (Glugea gigantea Thél.). (With Plates XVII and XVIII and 20 Diagrains).

Johnstone, James. Tetrarhynchus erinaceus van Beneden. I. Structure of larva and adult worm. (With Plates XIXXXIV and 9 Text-figures) . . . . . . . .

Lebour, Marie V. A review of the British marine Cercariae. (With Plates XXV-XXIX) . . . . . . . . 416

Huffman, Otro V. The Kurloff-body, a spurious parasite. (With 11 Text-figures) . . . . . . . . . . . . . 457

Hindle, E. On the life-cycle of Spirochaeta gallinarum. Preliminary

Note. (With 5 Figures and Diagram in Text) . . . . 463

Robinson, L. E. New species of ticks (Haemaphysalis, Amblyomma).

(With 4 Text-figures) . . . . . . . . . 478

INDEx of AUthors . . . . . . . . . . . . . . 485

INDEX of SUbJeCts . 